\title{
Theme based designing: A world of new opportunity for home furnishings by using $\mathrm{CAD}$
}

\author{
ANITA RUHIL, NIRMAL YADAV AND NISHA ARYA
}

Received: 27.01.2017; Revised: 05.05.2017; Accepted: 21.05.2017

See end of the paper for authors' affiliations

\section{ANITA RUHIL}

Department of Textile and Apparel

Designing, I.C. College of Home Science,

C.C.S. Haryana Agricultural University,

HISAR (HARYANA) INDIA

Email : anitahau05@gmail.com
ABSTRACT : Home furnishings are one of the most demanding and emerging fields, full of scope of innovation and creativity. Consumer choices in home decoration keeps on changing from time to time, due to changing fashion trends as well as need for comfortable home environment. So there is a great demand for theme based designing. An attempt was made through this study. Ten theme based design line were created for home furnishings by using different designing software's in 2D and 3D rendering in virtual design drawing cum lounge area. Themes include Black and white (accented neutral colour scheme), contemporary with polka dots, Floral, Natural botanical, Ocean, Silhouette, Sunrise, Traditional, Tribal and Zodiac.

KEY WORDS: Theme, Home furnishings, Consumer, CAD, Design, Home

- HOW TO CITE THIS PAPER : Ruhil, Anita, Yadav, Nirmal and Arya, Nisha (2017). Theme based designing: A world of new opportunity for home furnishings by using CAD. Asian J. Home Sci., 12 (1) : 257-263, DOI: 10.15740/HAS/AJHS/12.1/257-263. 